\title{
Assessment of trace metal in macroalgae and sediment of the Sundarban mangrove estuary
}

\author{
Ayesha Siddiqua Asha ${ }^{1}$ - A. S. M. Saifullah ${ }^{1} \cdot$ Md. Galal Uddin ${ }^{2} \cdot$ Md. Shemul Sheikh ${ }^{1}$ Muhammad Jasim Uddin ${ }^{1}$. \\ Mir Talas Mahammad Diganta ${ }^{1}$
}

Received: 9 February 2019 / Accepted: 23 December 2019 / Published online: 6 January 2020

(c) The Author(s) 2020

\begin{abstract}
This study was carried out to assess the levels of trace metals ( $\mathrm{Fe}, \mathrm{Zn}, \mathrm{Mn}$ and $\mathrm{Cu}$ ) in the macroalgae and sediment of the Sundarban mangrove estuary in Bangladesh. In this connection, macroalgae, water and sediment samples were collected seasonally (pre-monsoon, monsoon and post-monsoon) for a year from the study area. The surface water of the estuary was found to be quite rich in $\mathrm{NO}_{3}, \mathrm{PO}_{4}$ and $\mathrm{NH}_{4}$, which is more than that of the sediment pore water. Trace elements were determined using an atomic absorption spectrophotometer. The amount of trace metals in the samples were found in the order of $\mathrm{Fe}>\mathrm{Mn}>\mathrm{Zn}>\mathrm{Cu}$. Enrichment factor was done for trace metals in sediment and showed non-crustal origin of $\mathrm{Zn}$ and $\mathrm{Cu}$ in the monsoon period. Analysis of variance revealed the seasonal variation of trace metal concentration in sediment (except Mn; $p>0.05$ ) and macroalgae (except $\mathrm{Zn} ; p>0.05$ ). Iron in sediment showed significant positive correlation both with $\mathrm{Fe}(r=0.84, p<0.05)$ and $\mathrm{Mn}(r=0.87, p<0.01)$ in macroalgae. Similarly, $\mathrm{Cu}$ in sediment demonstrated a significant positive correlation with $\mathrm{Cu}$ in macroalgae $(r=0.81, p<0.01)$. The findings reveal a significant communication of metals in sediment and macroalgae.
\end{abstract}

Keywords Trace metals $\cdot$ Macroalgae $\cdot$ Sediment $\cdot$ Water nutrient $\cdot$ Sundarban mangrove $\cdot$ Estuarine ecosystem

\section{Introduction}

Estuaries are considered to be significant reservoir of trace metals that have originated from both anthropogenic and natural sources. As a favourable site for human settlement and industrial activities, estuaries become polluted with a wide variety of organic and inorganic contaminants derived from municipal and industrial sources, agricultural runoff, recreational boating, commercial shipping and other points (Tam and Wong 1995; Townend 2002; Melville and Pulkownik 2006). The coastal metropolitan areas discharge a huge amount of industrial and domestic wastes that led the pollution in coastal estuaries and affect marine communities

A. S. M. Saifullah

saifullahasm@yahoo.com

1 Department of Environmental Science and Resource Management, Mawlana Bhashani Science and Technology University, Tangail 1902, Bangladesh

2 Designated Reference Institute for Chemical Measurement (DRiCM), Bangladesh Council of Scientific and Industrial Research (BCSIR), Dhaka 1205, Bangladesh
(Amado Filho and Pfeiffer 1998). Trace elements those discharged with municipal and industrial wastes are significantly accumulated by many marine and estuarine species. The accumulation of pollutants gives rise to concerns of the possible detrimental effects of toxic substances on coastal resources and their potential impacts on human health (Hatje et al. 2009; Brito et al. 2012). Trace metals like $\mathrm{Cu}, \mathrm{Zn}$, $\mathrm{Fe}$, and $\mathrm{Mn}$ are essential for aquatic biota to a specific concentration, but they can become toxic if their concentration level in the environment is high (Yap et al. 2003). Thus, it is essential in detecting the sources of such pollutants and measuring trace elements concentration and distribution in the marine environment for better understanding of their behaviour and fate in the aquatic environment (Kumar et al. 2010). Macroalgae and seagrasses are used as biomonitors of metal pollution in many continents, although it is more difficult to assess the amounts of trace elements accumulated in the latter because of their capacity to incorporate elements from both the sediments and the water column (Phillips 1990; Villares et al. 2005). Biomonitoring of metals using macroalgae has been reported in many geographic regions including the Sarawak Malaysia (Billah et al. 2017), 
Egyptian Mediterranean coast (El-Din et al. 2014), Aegean coast (Akcali and Kucuksezgin 2011; Sawidis 2001), Indian coast (Chakraborty et al. 2014), Australia (Melville \& Pulkownik 2007) Tyrrhenian coastal areas (Conti and Cecchetti 2003), Aughinish Bay, Ireland (Reis et al. 2016), Polish coast (Rajfur and Kłos 2014; Ozyigit et al. 2017), Malaysian coast (Mashitah et al. 2012), and Sudanese Red Sea coast (Ali et al. 2017).

The Sundarban mangrove forest in Bangladesh coast is the harbour of large diverse macroalgae. Various species of macroalgae are abundant in water, pneumatophores and prop root of mangroves which can play a vital role in detecting trace metal concentration. Moreover, tidal activities induced erosion and physical mixing of the sediments, runoff, oil spillage, industrial activities like discharges from ports and urban area are common in this region. Trace metal concentration has been determined by many researchers (Chatterjee et al., 2009; Filho et al. 2011; Islam and Wahab 2005) in water and sediment of Sundarban mangrove estuary in both part of Bangladesh and India, but no such research has been conducted to determine the concentration of trace element in macroalgae in the Sundarban yet. It is significant to investigate and reveal the potential of macroalgae as a natural bioindicator for trace metal contamination in the Sundarban estuarine ecosystem. To fulfil the gaps, the present research has been conducted with the objectives of estimation of the trace metal concentration in mangrove macroalgae associated with pneumatophore and sediment and to evaluate the potentiality of macroalgae as natural bioindicator test species for metal pollution. The findings of this study would be relevant in coming up with strategies on how to address metallic pollution in estuaries.

\section{Materials and methods}

\section{Study area}

The Sundarban mangrove forest is the single largest continuous mangrove forest in the world and intersected by the number of river estuaries. The forest has already been recognized as an international Ramsar Wetland Site and declared as a World Heritage Site (WHS) by the UNESCO in 1997. The Sundarban forests tract covered an area of $10,000 \mathrm{~km}^{2}$ of which $66 \%$ are land and the remaining is water (Rashid et al. 2008). Samples were collected from five sampling stations which encompassed Dhanghmari (22 ${ }^{\circ} 43^{\prime} 72.74^{\prime \prime} \mathrm{N}$ and $\left.89^{\circ} 58^{\prime} 83.2^{\prime \prime} \mathrm{E}\right)$, and Koromjol $\left(22.43^{\circ} \mathrm{N}\right.$ and $\left.89.592^{\circ} \mathrm{E}\right)$ of Passur River estuary (Fig. 1). Sampling stations were selected on the basis of topography and the availability of macroalgae adhered to pneumatophores.

\section{Sample collection}

\section{Macroalgae in pneumatophore}

Macroalgae associated with pneumatophores were collected seasonally (pre-monsoon, monsoon, and post-monsoon) for the metal analysis. Pneumatophores were cut randomly at mud line with clipper from each transect in the sub-littoral zone $(0.5-3.0 \mathrm{~m})$ of the selected sites during low tide when the mangrove foreshore is exposed. Collected pneumatophores were kept in a plastic bag and transported to the laboratory under cool conditions.

\section{Sediment}

Intertidal surface sediment $(5-10 \mathrm{~cm})$ samples were collected in triplicate from each station with the plastic trowel. After cleaning the surface litter, samples were sealed in plastic bags and kept cooler box during transportation to the laboratory for analysis. Sediment samples were air-dried for 3 weeks prior to the analysis.

\section{Water}

The estuarine surface water quality parameters such as temperature, $\mathrm{pH}$ and dissolved oxygen (DO) were measured in situ using water pH meter (Model AD1000) and DO meter (PDO 519). The surface water and sediment pore water samples were collected in preconditioned (pre-washed in $10 \%$ nitric acid) $500-\mathrm{mL}$ polyethylene bottles from each sampling stations in triplicate for nutrient analysis. The collected water samples were filtered using a Millipore filtering system (MFS). Filtered samples were acidified by adding $2 \mathrm{~mL}$ of concentrated nitric acid in each $100 \mathrm{~mL}$ sample.

\section{Determination of water nutrients}

Dissolved inorganic nitrate $\left(\mathrm{NO}_{3}\right)$, phosphate $\left(\mathrm{PO}_{4}\right)$, and ammonium $\left(\mathrm{NH}_{4}\right)$ in both the surface and pore water samples were determined following the methods described by Kitamura et al. (1982), Weatherburn (1967), and Parsons (1984), respectively.

\section{Trace metal analysis for macroalgae and sediment}

For the determination of metal (iron, zinc, manganese, and copper), the macroalgae samples were scrapped off from each segment of pneumatophore taking care of not removing the pneumatophore tissue. Algal samples were then washed thoroughly to remove any adhering sediment particles and separated onto small glass Petri dishes. The samples were 
Fig. 1 Map of the study area mentioning sampling stations

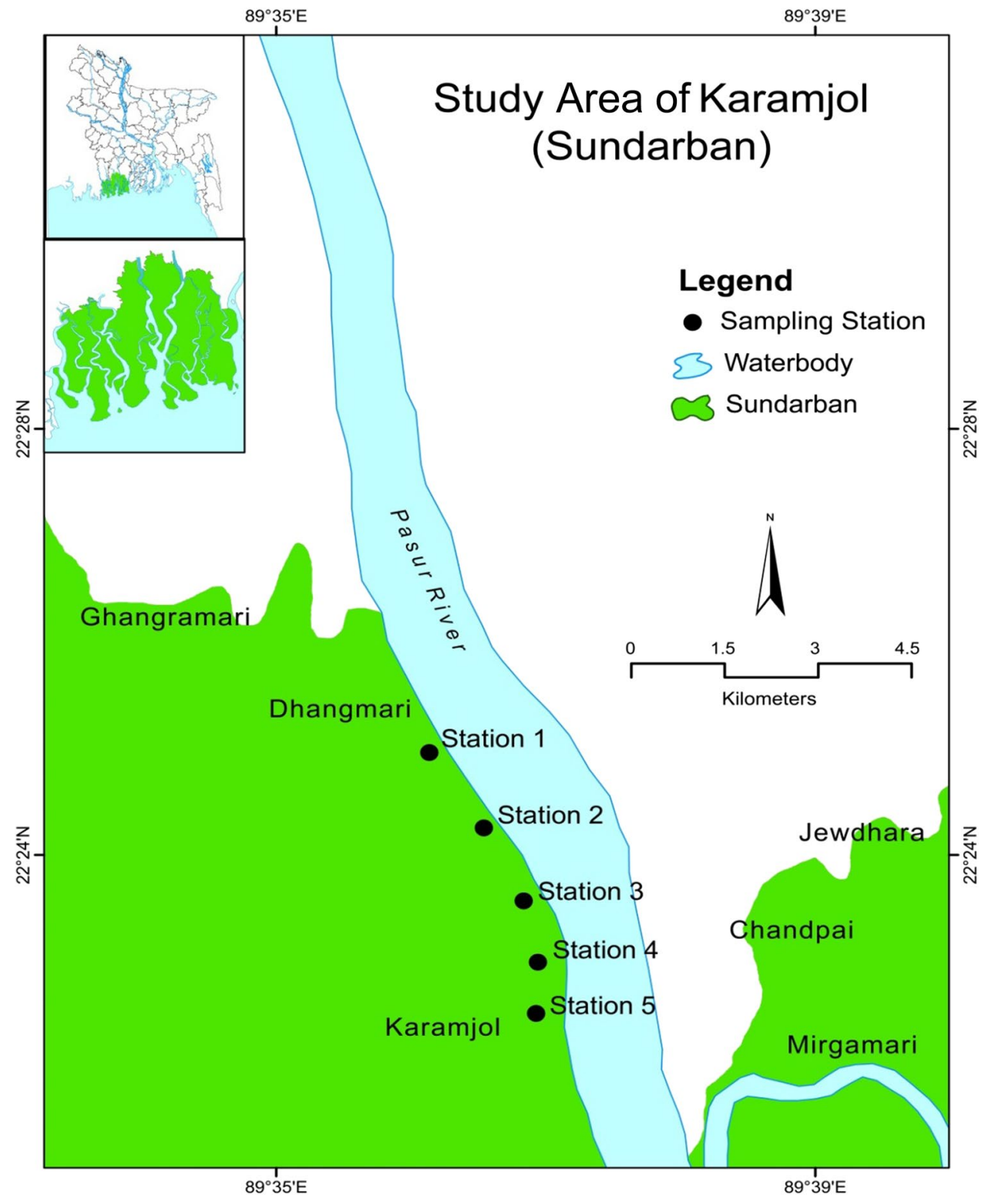

placed in the oven and dried at $105^{\circ} \mathrm{C}$ overnight $(12 \mathrm{~h})$; then dried material was ground to fine powder according to the method described by Gopinath et al. (2011). While sediment samples were placed in the oven and dried at $105^{\circ} \mathrm{C}$ overnight (12 h), dried sediments were mortared to the fine powder and sieved through a 300 BSS mesh sieve. Acid digestion of both macroalgae and sediment samples was performed by using high-pressure laboratory microwave oven following the EPA-3050B method. The concentration of the common contaminant metals, e.g., iron, zinc, manganese and copper, was determined from the digested macroalgae filtrates as dry weight basis (ppm or $\mu \mathrm{g} \mathrm{g}^{-1}$ dry weight) using a
Shimadzu AA-7000 Atomic Absorption Spectrophotometer in Designated Reference Institute for Chemical Measurements (DRiCM) following the procedure of American Water Works Association (AWWA 3113B).

\section{Enrichment factor (EF)}

Enrichment factor is an effective method to estimate the anthropogenic impact on sediments (Huang et al. 2014). Enrichment factor (EF) was estimated using normalization of metal concentrations above uncontaminated background levels (Kumar et al. 2012). The enrichment factor is based on 
the standardization of a tested element against a reference. A reference element is the one characterized by low occurrence variability. The most common reference elements are $\mathrm{Sc}$, Mn, Ti, Al, and Fe (Sutherland 2000). In the present study, Fe was used as the reference ( $\left.C_{\text {ref }}\right)$ element for EF calculations using the following equation

$\mathrm{EF}=\frac{\left(\frac{c_{x}}{c_{\text {ref }}}\right) \text { sample }}{\left(\frac{c_{x}}{c_{\text {ref }}}\right) \text { background }}$

where $C_{x}=$ concentration of the element of interest and, $C_{\text {ref }}=$ concentration of the reference element for normalization.

In the present study, the background levels (i.e., the average contents of elements in the Earth's crust) given by Rudnick and Gao (2004) were employed for each of the trace metals investigated. The EF values close to unity indicate crustal origin and $\mathrm{EF}<1.0$ suggests a possible mobilization or depletion of elements (Zsefer et al. 1996). According to EF classification, the EF values 1.5-3.0, 3.0-5.0, 5.0-10 and $>10$ are the prominent evidence of minor, moderate, severe and very severe contamination of the elements in the sediments, respectively (Brich and Olmos 2008).

\section{Statistical analyses}

Pearson correlation coefficient was used for checking any significant relationship among the parameters tested. Oneway ANOVA was likewise carried out to determine the seasonal variations of different factors. For both cases of analyses, the Statistical Package for Social Science (IBM SPSS Statistics 20.0) was used. The results of the statistical analyses are further elaborated in the succeeding section, and findings are the bases for coming up with inferences relevant in providing recommendations.

\section{Results and discussion}

\section{Environmental parameters}

In the pre-monsoon season, surface water temperature ranged from $27.4{ }^{\circ} \mathrm{C}$ to $28.8{ }^{\circ} \mathrm{C}$ and $29.3{ }^{\circ} \mathrm{C}$ to $30{ }^{\circ} \mathrm{C}$ in the post-monsoon season (Table 1 ). The maximum temperature $\left(33.2{ }^{\circ} \mathrm{C}\right)$ was recorded in the early monsoon (Table 1$)$. Significant seasonal variation of surface water temperature $(d f=2, F=166.4, p<0.05)$ was observed (Table 4). Mostly similar observation to the present study was reported by Rahman et al. (2013) in the Passur River, Sundarban; Billah et al. (2016) in Miri estuary, and Saifullah et al. (2014) in
Table 1 Mean values of environmental parameters in different season at Sundarban

\begin{tabular}{lllll}
\hline Season & Station & SWT $\left({ }^{\circ} \mathrm{C}\right)$ & pH & DO $(\mathrm{mg} / \mathrm{L})$ \\
\hline Pre-monsoon & St 01 & $27.4 \pm 0.51$ & $8.10 \pm 0.07$ & $7.50 \pm 0.36$ \\
& St 02 & $28.8 \pm 0.50$ & $8.03 \pm 0.02$ & $7.33 \pm 0.70$ \\
& St 03 & $28.4 \pm 0.35$ & $8.08 \pm 0.04$ & $8.26 \pm 1.73$ \\
& St 04 & $28.2 \pm 0.20$ & $8.08 \pm 0.04$ & $7.80 \pm 1.44$ \\
Monsoon & St 05 & $27.7 \pm 0.30$ & $8.15 \pm 0.03$ & $8.73 \pm 0.55$ \\
& St 01 & $33.2 \pm 0.05$ & $7.19 \pm 0.03$ & $7.50 \pm 0.17$ \\
& St 02 & $33.03 \pm 0.20$ & $7.19 \pm 0.07$ & $7.16 \pm 0.05$ \\
& St 03 & $32.6 \pm 0.4$ & $7.26 \pm 0.01$ & $6.73 \pm 0.49$ \\
Post-monsoon & St 04 & $33.2 \pm 0.17$ & $7.22 \pm 0.02$ & $6.70 \pm 0.17$ \\
& St 05 & $32.1 \pm 0.52$ & $7.28 \pm 0.02$ & $6.66 \pm 0.40$ \\
& St 01 & $29.5 \pm 0.5$ & $7.38 \pm 0.04$ & $2.83 \pm 0.47$ \\
& St 02 & $29.8 \pm 0.76$ & $7.46 \pm 0.07$ & $2.56 \pm 0.47$ \\
& St 03 & $29.4 \pm 0.52$ & $7.44 \pm 0.03$ & $2.96 \pm 0.20$ \\
& St 04 & $29.3 \pm 0.65$ & $7.55 \pm 0.04$ & $5.26 \pm 0.15$ \\
& St 05 & $30.0 \pm 0.26$ & $7.48 \pm 0.05$ & $5.43 \pm 0.37$ \\
\hline
\end{tabular}

$S W T$ surface water temperature, $D O$ dissolved oxygen

Sibuti mangrove estuary in Malaysia. The maximum water $\mathrm{pH}$ was observed in the pre-monsoon (8.15) and minimum in the post-monsoon season (7.19) (Table 1). A negative correlation $(r=-0.80, p<0.01)$ between the surface water temperature and the $\mathrm{pH}$ was revealed (Table 3 ). The water $\mathrm{pH}$ reported by Rahman et al. (2003) mostly coincided with the present study. The present findings indicated that the water of the Passur River is alkaline $(\mathrm{pH}>7)$, and there were insignificant variations between the sampling stations. Dissolved oxygen was maximum $(8.73 \mathrm{mg} / \mathrm{L})$ in the premonsoon and minimum $(2.56 \mathrm{mg} / \mathrm{L})$ in the post-monsoon (Table 1). Chakraborty et al. (2015) also found considerably higher DO during pre-monsoon season, and the most similar pattern was observed in the study of Hoque et al. (2015).

\section{Water nutrients in surface and sediment pore water}

The concentration of nitrate $\left(\mathrm{NO}_{3}\right)$ in surface water was found to be higher in the monsoon $(0.11 \mathrm{mg} / \mathrm{L})$ and lower in the pre-monsoon season $(0.02 \mathrm{mg} / \mathrm{L})$ (Table 2$)$. While, in sediment pore water, the maximum concentration of $\mathrm{NO}_{3}$ was found in the pre-monsoon season $(0.28 \mathrm{mg} / \mathrm{L})$ and minimum in the post-monsoon season. $(0.02 \mathrm{mg} / \mathrm{L})$ (Table 2). Generally, the concentration of nitrate in surface water remains higher during the monsoon season which could be due to the freshwater influx (Kumar et al. 2009). Land drainage and precipitation could also increase the concentration of nitrate during the monsoon season (Sarkar and Bhattacharya 2010). The nitrate content 
Table 2 Water nutrients in surface and sediment pore water of Passur River estuary, Sundarban

\begin{tabular}{|c|c|c|c|c|c|c|c|}
\hline Season & Station & $\mathrm{SW} \mathrm{NO}_{3}(\mathrm{mg} / \mathrm{L})$ & $\mathrm{SW} \mathrm{PO}{ }_{4}(\mathrm{mg} / \mathrm{L})$ & $\mathrm{SW} \mathrm{NH}_{4}(\mathrm{mg} / \mathrm{L})$ & $\mathrm{SPW} \mathrm{NO}_{3}(\mathrm{mg} / \mathrm{L})$ & $\mathrm{SPW} \mathrm{PO}_{4}(\mathrm{mg} / \mathrm{L})$ & $\mathrm{SPW} \mathrm{NH}_{4}(\mathrm{mg} / \mathrm{L})$ \\
\hline \multirow[t]{5}{*}{ Pre-monsoon } & St 01 & $0.06 \pm 0.01$ & $2.13 \pm 0.08$ & $0.04 \pm 0.02$ & $0.25 \pm 0.13$ & $0.07 \pm 0.005$ & $0.03 \pm 0.010$ \\
\hline & St 02 & $0.04 \pm 0.01$ & $1.99 \pm 0.07$ & $0.03 \pm 0.008$ & $0.28 \pm 0.08$ & $0.09 \pm 0.004$ & $0.02 \pm 0.01$ \\
\hline & St 03 & $0.05 \pm 0.009$ & $2.14 \pm 0.17$ & $0.07 \pm 0.05$ & $0.06 \pm 0.001$ & $0.09 \pm 0.02$ & $0.04 \pm 0.007$ \\
\hline & St 04 & $0.05 \pm 0.008$ & $2.10 \pm 0.01$ & $0.03 \pm 0.01$ & $0.22 \pm 0.15$ & $0.04 \pm 0.047$ & $0.08 \pm 0.07$ \\
\hline & St 05 & $0.06 \pm 0.01$ & $2.18 \pm 0.09$ & $0.06 \pm 0.01$ & $0.11 \pm 0.09$ & $0.01 \pm 0.001$ & $0.03 \pm 0.006$ \\
\hline \multirow[t]{5}{*}{ Monsoon } & St 01 & $0.11 \pm 0.05$ & $0.60 \pm 0.02$ & $0.05 \pm 0.03$ & $0.06 \pm 0.02$ & $0.05 \pm 0.01$ & $0.05 \pm 0.008$ \\
\hline & St 02 & $0.07 \pm 0.03$ & $0.57 \pm 0.01$ & $0.03 \pm 0.01$ & $0.06 \pm 0.01$ & $0.03 \pm 0.02$ & $0.05 \pm 0.01$ \\
\hline & St 03 & $0.03 \pm 0.008$ & $0.56 \pm 0.04$ & $0.03 \pm 0.007$ & $0.04 \pm 0.007$ & $0.06 \pm 0.01$ & $0.05 \pm 0.02$ \\
\hline & St 04 & $0.07 \pm 0.05$ & $0.55 \pm 0.07$ & $0.03 \pm 0.005$ & $0.04 \pm 0.009$ & $0.07 \pm 0.02$ & $0.04 \pm 0.02$ \\
\hline & St 05 & $0.03 \pm 0.01$ & $0.49 \pm 0.01$ & $0.05 \pm 0.03$ & $0.09 \pm 0.10$ & $0.05 \pm 0.02$ & $0.06 \pm 0.02$ \\
\hline \multirow[t]{5}{*}{ Post-monsoon } & St 01 & $0.02 \pm 0.004$ & $1.84 \pm 0.15$ & $0.02 \pm 0.006$ & $0.03 \pm 0.004$ & $1.47 \pm 0.07$ & $0.02 \pm 0.006$ \\
\hline & St 02 & $0.02 \pm 0.003$ & $2.07 \pm 0.25$ & $0.12 \pm 0.09$ & $0.02 \pm 0.007$ & $1.51 \pm 0.181$ & $0.07 \pm 0.024$ \\
\hline & St 03 & $0.10 \pm 0.14$ & $1.83 \pm 0.078$ & $0.22 \pm 0.24$ & $0.04 \pm 0.007$ & $1.62 \pm 0.103$ & $0.14 \pm 0.14$ \\
\hline & St 04 & $0.02 \pm 0.003$ & $1.81 \pm 0.127$ & $0.13 \pm 0.103$ & $0.04 \pm 0.002$ & $1.72 \pm 0.103$ & $0.18 \pm 0.06$ \\
\hline & St 05 & $0.02 \pm 0.001$ & $1.91 \pm 0.17$ & $0.28 \pm 0.015$ & $0.02 \pm 0.007$ & $1.82 \pm 0.034$ & $0.14 \pm 0.12$ \\
\hline
\end{tabular}

$S W$ surface water, $S P W$ sediment pore water

found in the present study is quite similar to that reported by Wahid et al. (2007). The concentration of phosphate $\left(\mathrm{PO}_{4}\right)$ in surface water was maximum in the pre-monsoon season $(2.18 \mathrm{mg} / \mathrm{L})$. During the monsoon and post-monsoon season, phosphate concentration ranged between 0.49-0.60 mg/L and 1.81-2.07 mg/L, respectively, while phosphate content in sediment pore water was maximum in the post-monsoon season $(1.82 \mathrm{mg} / \mathrm{L})$. Almost similar seasonal distribution pattern of phosphate in the water of Passur River was reported by Rahman et al. (2013). Ammonium $\left(\mathrm{NH}_{4}\right)$ concentration in the surface water was found to be higher $(0.28 \mathrm{mg} / \mathrm{L})$ in the pre-monsoon and lower $(0.02 \mathrm{mg} / \mathrm{L})$ in the post-monsoon season (Table 2$)$. In the monsoon season, it ranged from $0.03 \mathrm{mg} / \mathrm{L}$ to
$0.05 \mathrm{mg} / \mathrm{L}$ for surface water. For sediment pore water, ammonium concentration was higher in the post-monsoon season $(0.18 \mathrm{mg} / \mathrm{L})$ and lower in the pre-monsoon season (0.02 mg/L) (Fig. 2). Rahman et al. (2015) reported the higher concentration of ammonium in the surface water of the Passur River in the post-monsoon season. Another research by Hoq (2007) also reported the similar pattern of ammonium distribution which mostly coincided with the present study.

\section{Trace metal concentration in sediment}

The concentration of Iron (Fe) was found higher than that of other trace metals detected. The maximum content of
Fig. 2 Sediment iron concentration $( \pm \mathrm{SD})$ variation at different seasons in different stations of Sundarban

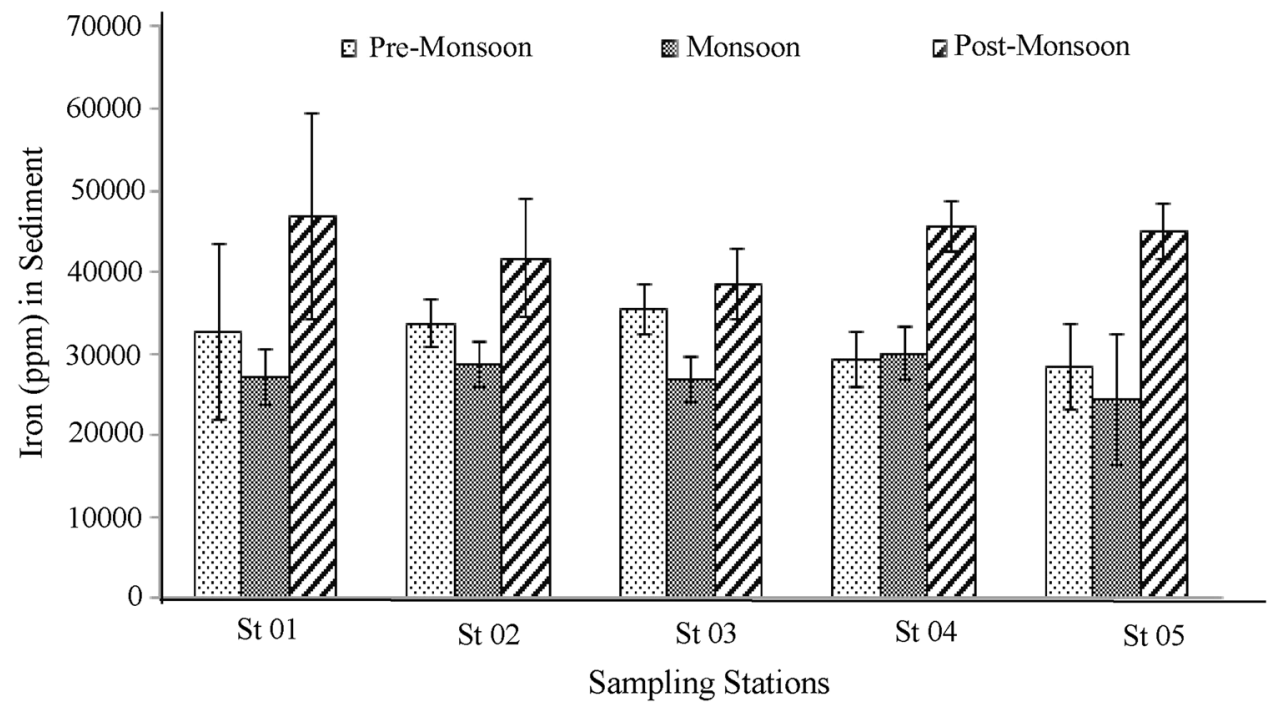

Sampling Stations 


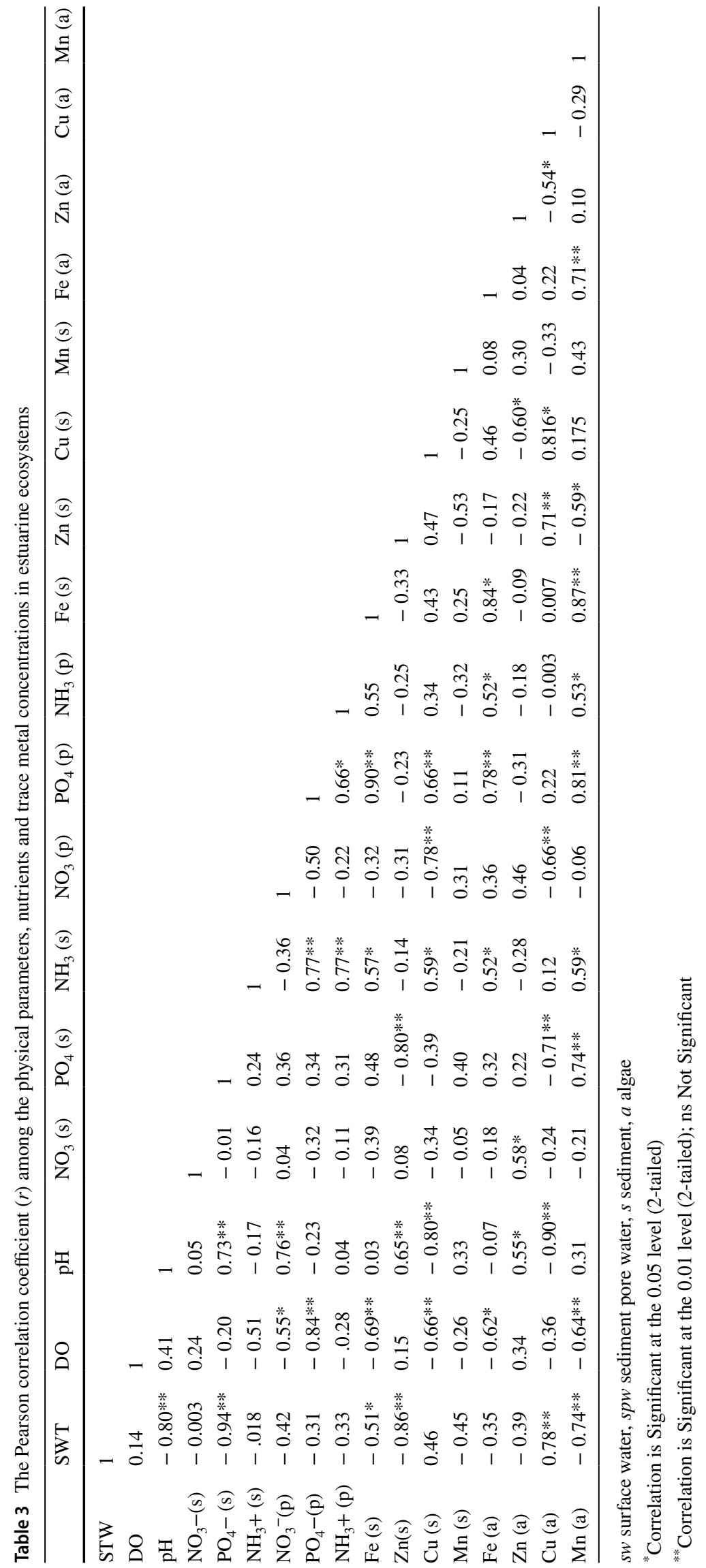


Table 4 Analysis of variance (ANOVA) in physicochemical characteristics of water and sediments among the seasons

\begin{tabular}{|c|c|c|c|c|}
\hline Parameter & Pre-monsoon $($ Mean \pm SD) & Monsoon $($ Mean \pm SD) & Post-monsoon (Mean \pm SD) & ANOVA \\
\hline $\operatorname{SWT}\left({ }^{\circ} \mathrm{C}\right)$ & $28.1 \pm 0.37$ & $32.8 \pm 0.26$ & $29.6 \pm 0.54$ & $d f=2, F=166.4, p<0.05$ \\
\hline $\mathrm{pH}$ & $8.08 \pm 0.04$ & $7.22 \pm 0.03$ & $7.46 \pm 0.04$ & $d f=2, F=81.43, p<0.05$ \\
\hline $\mathrm{DO}(\mathrm{mg} / \mathrm{L})$ & $7.9 \pm 0.95$ & $6.95 \pm 0.25$ & $3.8 \pm 0.03$ & $d f=2, F=27.31, p<0.05$ \\
\hline $\mathrm{SW} \mathrm{NO}_{3}(\mathrm{mg} / \mathrm{L})$ & $0.04 \pm 0.01$ & $0.06 \pm 0.01$ & $0.04 \pm 0.003$ & $d f=2, F=0.789, p>0.05$ \\
\hline $\mathrm{SW} \mathrm{PO}_{4}(\mathrm{mg} / \mathrm{L})$ & $2.10 \pm 0.07$ & $0.55 \pm 0.03$ & $1.89 \pm 0.15$ & $d f=2, F=44.27, p<0.05$ \\
\hline $\mathrm{SW} \mathrm{NH}_{4}(\mathrm{mg} / \mathrm{L})$ & $0.04 \pm 0.02$ & $0.04 \pm 0.01$ & $0.15 \pm 0.03$ & $d f=2, F=6.65, p<0.05$ \\
\hline $\mathrm{SPW} \mathrm{NO}_{3}(\mathrm{mg} / \mathrm{L})$ & $0.18 \pm 0.03$ & $0.06 \pm 0.01$ & $0.03 \pm 0.005$ & $d f=2, F=10.46, p<0.05$ \\
\hline $\mathrm{SPW} \mathrm{PO} \mathrm{PO}_{4}(\mathrm{mg} / \mathrm{L})$ & $0.06 \pm 0.006$ & $0.05 \pm 0.01$ & $1.62 \pm 0.07$ & $d f=2, F=547.67, p<0.05$ \\
\hline $\mathrm{SPW} \mathrm{NH}_{4}(\mathrm{mg} / \mathrm{L})$ & $0.04 \pm 0.02$ & $0.05 \pm 0.02$ & $0.11 \pm 0.03$ & $d f=2, F=3.709, p>0.05$ \\
\hline $\mathrm{Fe}$ (Sediment) & $31,870.09 \pm 5042.7$ & $27,378.9 \pm 40,433.9$ & $43,461.4 \pm 6093.2$ & $d f=2, F=42.06, \mathrm{p}<0.05$ \\
\hline Mn (Sediment) & $359.8 \pm 114.8$ & $298.2 \pm 56.3$ & $347.6 \pm 42.2$ & $d f=2, F=1.600, p>0.05$ \\
\hline Zn (Sediment) & $74.7 \pm 12.2$ & $113.3 \pm 15.8$ & $84.05 \pm 13.4$ & $d f=2, F=13.83, p<0.05$ \\
\hline $\mathrm{Cu}$ (Sediment) & $7.7 \pm 3.9$ & $33.06 \pm 6.9$ & $40.96 \pm 15.9$ & $d f=2, F=75.34, p<0.05$ \\
\hline $\mathrm{Fe}($ Algae $)$ & $14,876.8 \pm 2687.2$ & $13,243.5 \pm 1186.04$ & $26,887.35 \pm 1819.7$ & $d f=2, F=9.77, p<0.05$ \\
\hline Mn (Algae) & $280.07 \pm 3.8$ & $49.06 \pm 2.7$ & $465.8 \pm 8.08$ & $d f=2, F=112.83, p<0.05$ \\
\hline Zn (Algae) & $66.9 \pm 4.1$ & $48.03 \pm 2.3$ & $48.3 \pm 2.1$ & $d f=2, F=4.034, p>0.05$ \\
\hline $\mathrm{Cu}$ (Algae) & $5.06 \pm 1.2$ & $38.2 \pm 2.7$ & $28.8 \pm 1.4$ & $d f=2, F=85.32, p<0.05$ \\
\hline
\end{tabular}

$d f$ degree of freedom, $F$ test of model fitting, $p$ significance level, $S W T$ surface water temperature, $S W$ surface water

Fe was observed in the post-monsoon $(46,771.67 \mathrm{ppm})$ and the lowest in the monsoon $(24,443.33 \mathrm{ppm})$. The present finding coincided with the concentration of $\mathrm{Fe}$ $(42,172.17 \mu \mathrm{g} / \mathrm{g})$ detected by Kumar et al. (2016) in the sediment of Sundarban. Significant seasonal variation was observed in sediment iron $(d f=2, F=42.06, p<0.05$; Table 4). The pore water phosphate demonstrated a strong positive relationship ( $r=0.90, p<0.01)$ with $\mathrm{Fe}$ (Table 3 ). Billah et al. (2014) also reported the higher concentration of $\mathrm{Fe}$ in the sediment of an estuary in Malaysia. The amount of $\mathrm{Zn}$ was found to be higher (142.70 ppm) in the monsoon followed by the post-monsoon $(90.8 \mathrm{ppm})$ and pre-monsoon $(89.25 \mathrm{ppm})$. Analysis of variance revealed seasonal variation of $\mathrm{Zn}$ concentration in sediment $\mathrm{Zn}$ $(d f=2, F=13.83, p<0.05)$. Zn showed the negative correlation $(r=-0.80, p<0.01)$ with surface water phosphate (Table 3). Melville and Pulkownik (2006) and Billah et al. (2014) found a higher concentration of $\mathrm{Zn}$ than that of present findings (Fig. 3). The maximum content of $\mathrm{Mn}$ (481.80 ppm) was found in the post-monsoon (Fig. 4). Manganese did not show any significant relationship with any other parameters (Table 3). Kumar et al. (2016) found
Fig. 3 Sediment zinc concentration $( \pm \mathrm{SD})$ variation at different seasons in different sampling stations of Sundarban mangrove estuary

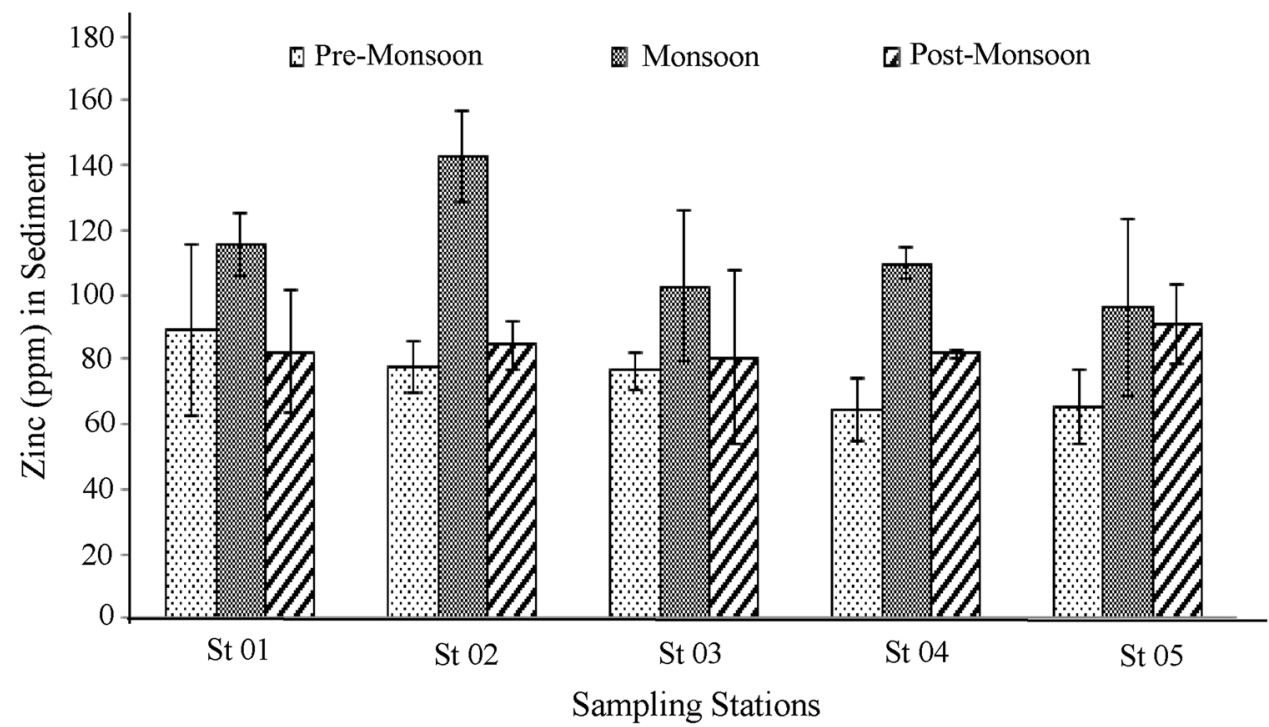

Sampling Stations 
Fig. 4 Sediment manganese concentration $( \pm \mathrm{SD})$ variation at different seasons in different sampling stations of Sundarban mangrove estuary
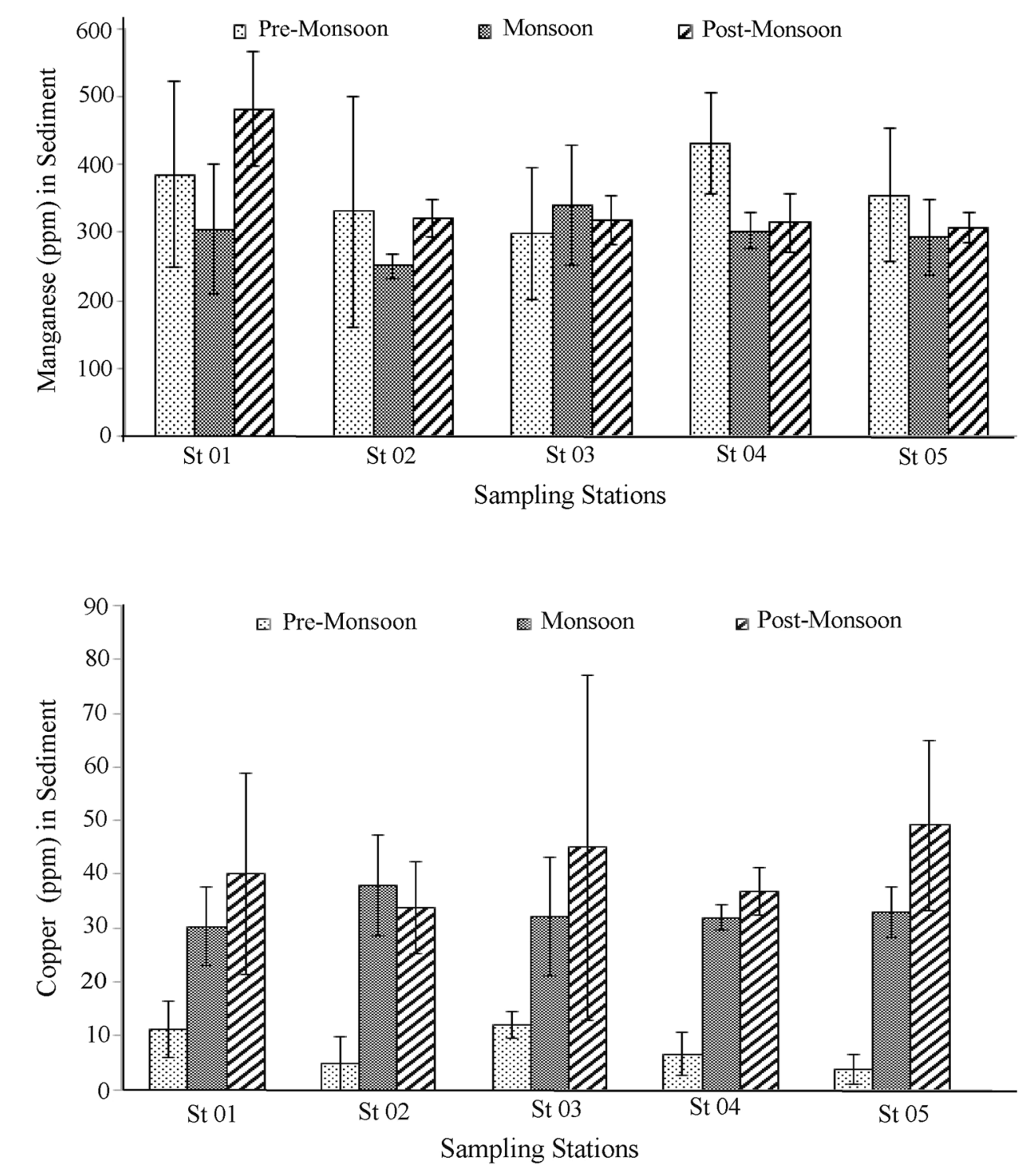

Fig. 5 Sediment copper concentration $( \pm S D)$ variation at different seasons in different sampling stations of Sundarban mangrove estuary the higher content of Mn $(740.95 \mu \mathrm{g} / \mathrm{g})$ in the sediment of the Sundarban mangrove estuary than that of the present study. The higher concentration $\mathrm{Cu}$ was found in the postmonsoon season (49.11 ppm) followed by the monsoon (37.95 ppm) (Fig. 5). Significant seasonal variation of $\mathrm{Cu}$ was observed in sediment $(d f=2, F=75.34, p<0.05)$ (Table 4).

\section{Enrichment factor}

The enrichment factor (EF) analysis has been commonly used to assess human-made contamination in sediment. It is based on the standardization of a tested element against a reference. In the present study, Fe was used as the reference element for EF calculations. The EF values of 0.5-1.5 reflect regional rock compositions, whereas $\mathrm{EF}$ values that are $>1.5$ indicate non-crustal contributions and/or non-natural weathering processes (e.g., anthropogenic influences) (Zhang and Liu 2002; Zhang and Shan 2008). In monsoon values of EF for $\mathrm{Zn}$ were found greater than 1.5, which indicated anthropogenic impact on the $\mathrm{Zn}$ levels in sediment (Fig. 6). However, EF values of Mn were found lower than 1.5 indicating natural or crustal origin (Fig. 7). Copper also showed EF values greater than 1.5 in the monsoon season (Fig. 8), which suggested non-crustal origin of $\mathrm{Cu}$.

\section{Trace metal concentration in macroalgae}

The maximum concentration $(28,960 \mathrm{ppm})$ of Fe in macroalgae was found in the post-monsoon and the minimum 
Fig. 6 Enrichment factor for Zinc

Fig. 7 Enrichment factor for Manganese

Fig. 8 Enrichment factor for copper

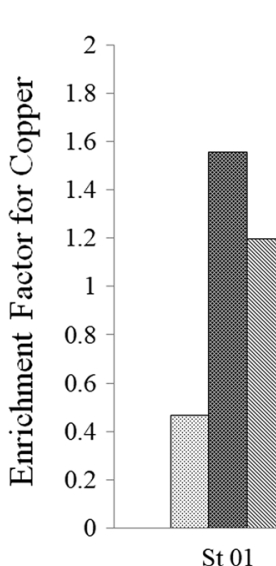

圆Pre-monsoon

Monsoon

$\mathbb{N}$ Post-monsoon

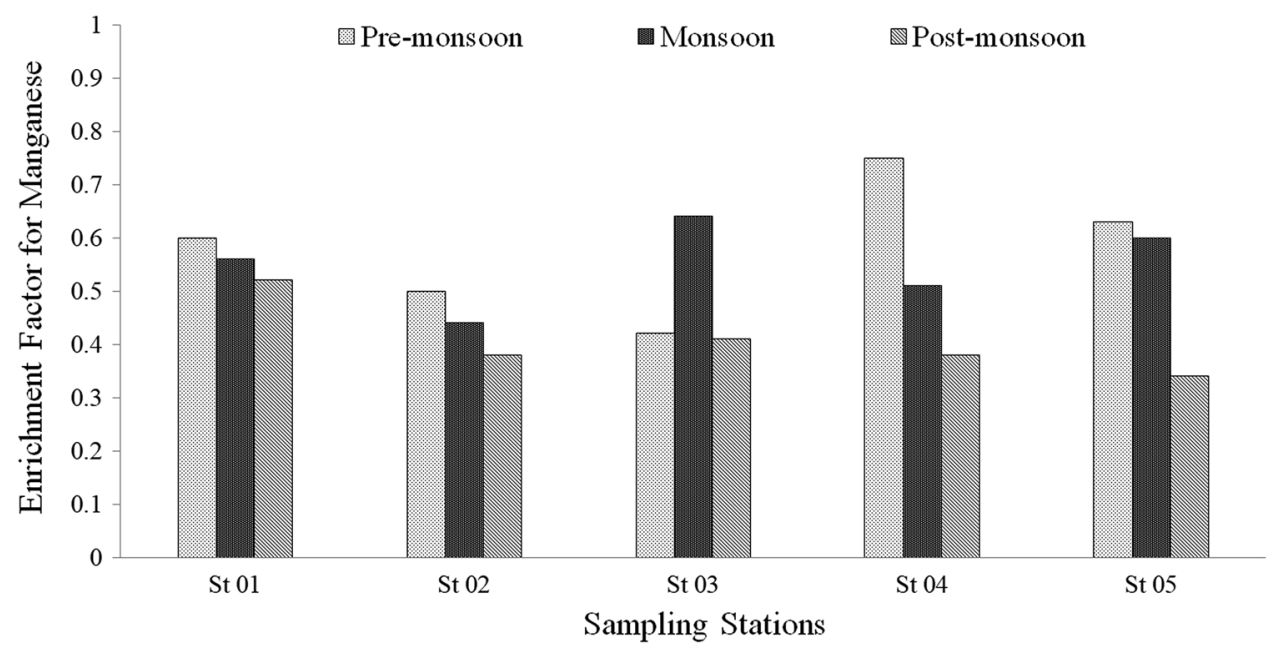

St 01

Pre-monsoon

Monsoon

$\mathbb{\mathbb { B }}$ Post-monsoon
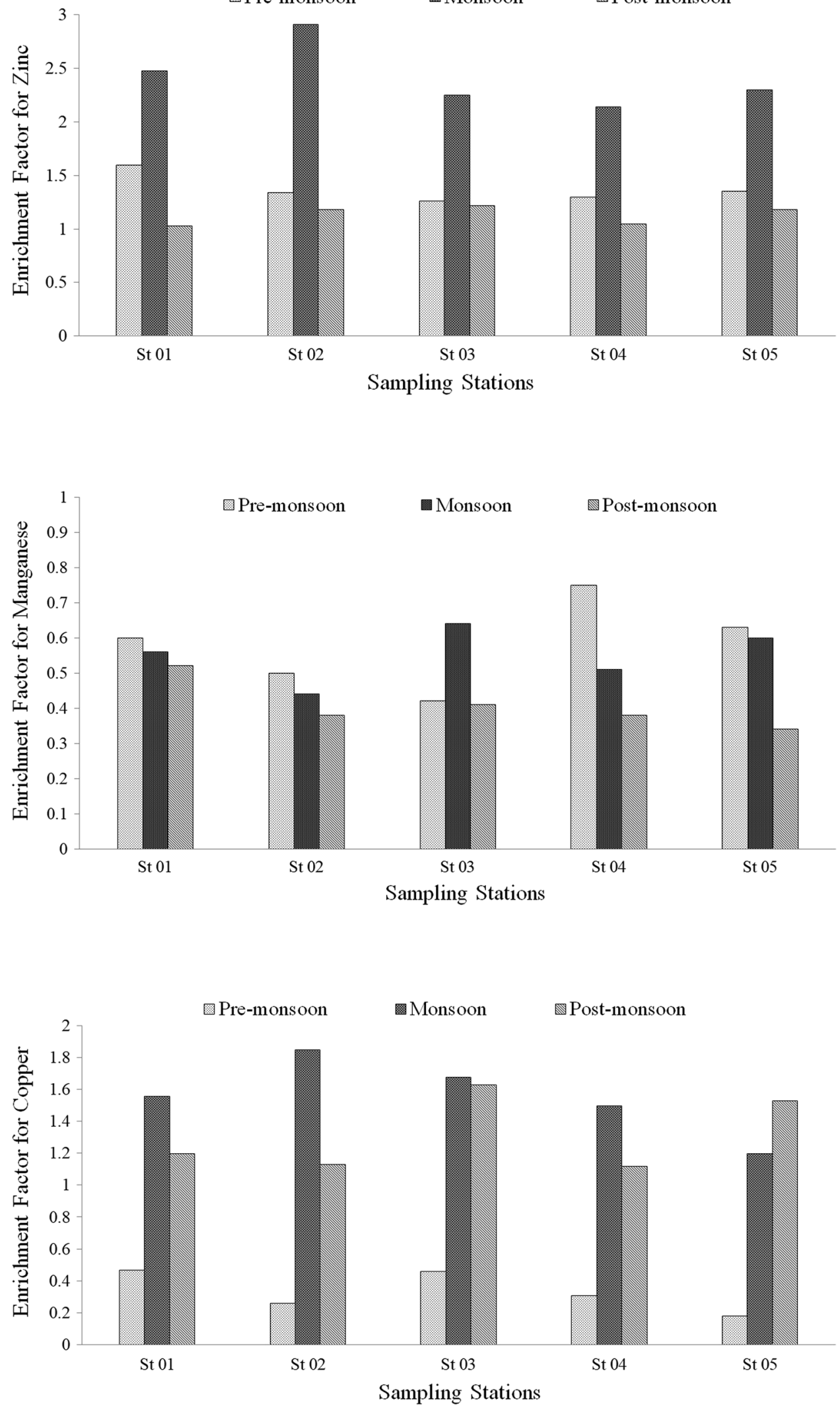
Fig. 9 Algal iron concentration $( \pm \mathrm{SD})$ variation at different seasons in different stations of Sundarban mangrove estuary

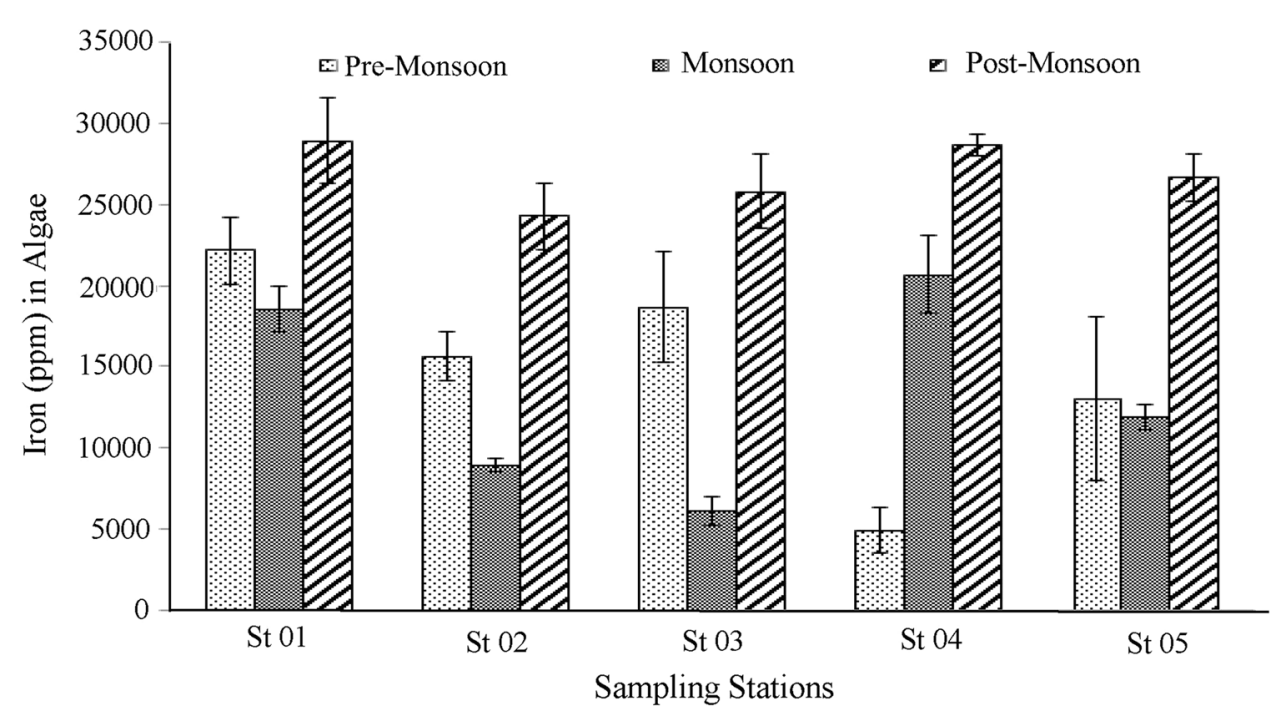

Fig. 10 Algal zinc concentration $( \pm S D)$ variation at different seasons in different stations of Sundarban mangrove estuary

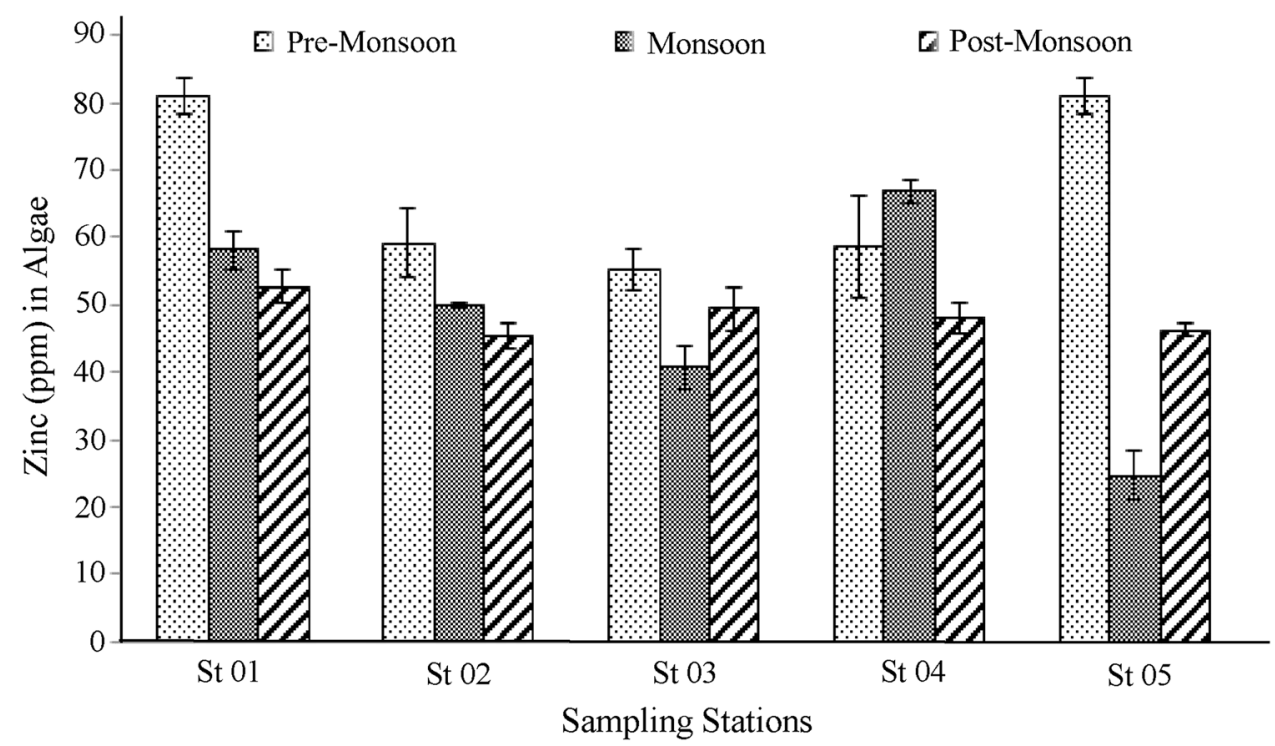

in the pre-monsoon (4901.07 ppm) (Fig. 9). Significant seasonal variation for $\mathrm{Fe}$ in macroalgae was confirmed through ANOVA ( $d f=2, F=9.77, p<0.05)$. It showed significant positive correlation $(r=0.84, p<0.05)$ with $\mathrm{Fe}$ in sediment (Table 3). The content of $\mathrm{Zn}$ was found to be higher in the pre-monsoon $(81 \mathrm{ppm})$ followed by the monsoon (66.82 ppm) and the post-monsoon (52.71 ppm) (Fig. 10). However, Zn concentration in macroalgae did not differ significantly ( $d f=2, F=4.034, p>0.05)$ among the sampling seasons. The maximum concentration of $\mathrm{Mn}(477.50 \mathrm{ppm})$ in macroalgae was found in the post-monsoon and the minimum in the monsoon (27.30 ppm) (Fig. 11). Profound seasonal variation of $\mathrm{Mn}$ in macroalgae was observed $(d f=2$,
$F=112.83, p<0.05)$. Mn also demonstrated significant positive correlation $(r=0.876, p<0.01)$ with $\mathrm{Fe}$ in sediment and $\mathrm{Fe}$ in macroalgae $(r=0.71, p<0.01)$. Chernova (2012) recorded the content of Mn $(12-455 \mu \mathrm{g} / \mathrm{g})$ in the macroalgae which mostly coincided with the findings of the present study. The concentration of $\mathrm{Cu}$ was found to be higher in the monsoon (42.72 ppm) and lower (1.45 ppm) in the pre-monsoon (Fig. 12). There was significant seasonal variation of $\mathrm{Cu}$ in macroalgae $(d f=2, F=85.32$, $p<0.05)$. The $\mathrm{Cu}$ concentration showed significant negative correlation $(r=-0.90, p<0.01)$ with $\mathrm{pH}$ and positive correlation $(r=0.81, p<0.01)$ with $\mathrm{Cu}$ in sediment (Table 3). 
Fig. 11 Algal manganese concentration $( \pm \mathrm{SD})$ variation stations of Sundarban mangrove estuary at different seasons in different

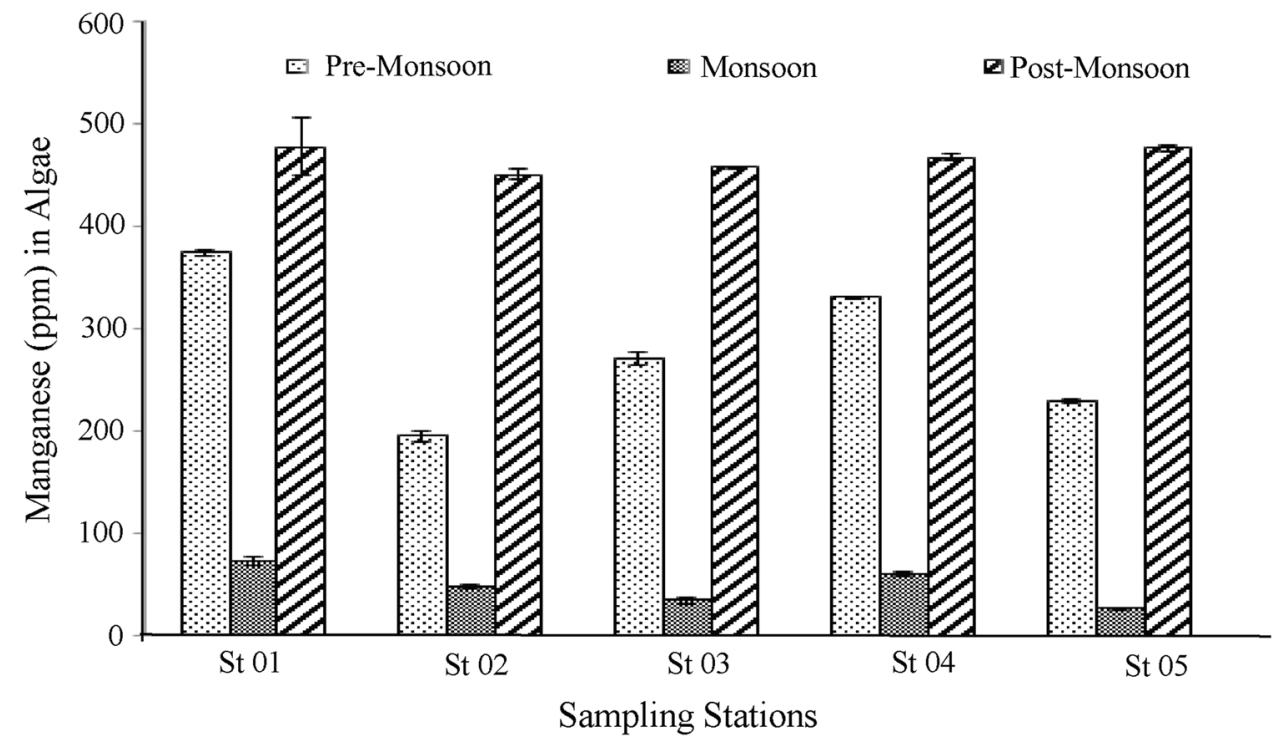

Fig. 12 Algal copper concentration $( \pm$ SD) variation at different seasons in different stations of Sundarban mangrove estuary

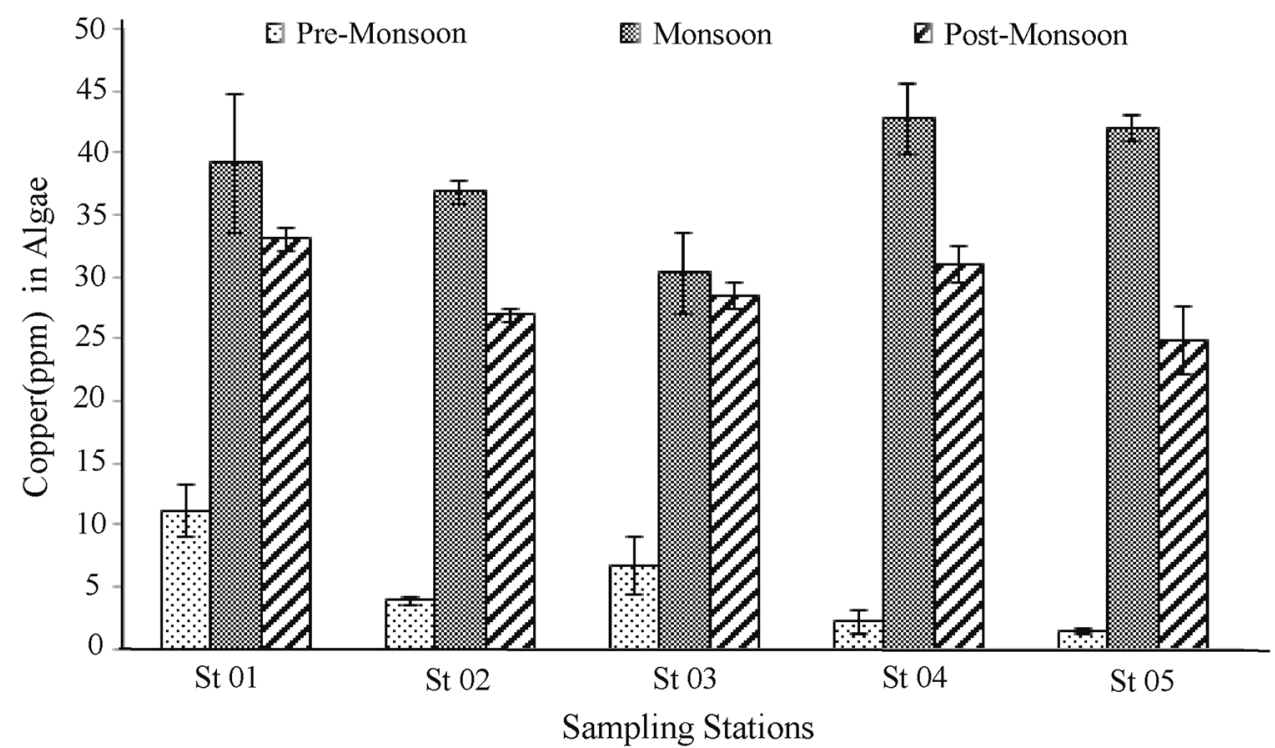

\section{Conclusion}

There has been very few information about the trace metal distribution in surface water and sediment and none for the macroalgae of the Sundarban. This might be the first initiative to assess trace metal accumulation in macroalgae in the Sundarban mangrove estuary in Bangladesh. The Sundarban mangrove estuary was (Dhangmari-Koromjol) found with more trace metals concentration than that of findings for other estuaries. This location is the entry point to the forest and possesses more anthropogenic activities. There revealed a succession of trace elements from sediment to macroalgae. Seasonal variation of trace element $(\mathrm{Mn}, \mathrm{Cu})$ was observed. The study has assessed the distribution of trace metals in macroalgae and sediments, which possess the ability to impact the estuarine ecosystem of the Sundarban. The heterogeneous distribution of these elements in this region might be ascribed to anthropogenic inputs coupled with erosion and physical mixing of the sediments, oil spillage, the fast development of industries, discharges from ports and urban area etc. Findings of this study also suggest that as a potential bioindicator, mangrove macroalgae can be used to assess the status of the estuarine ecosystem.

Acknowledgements The authors acknowledge the cooperation of the Department of Environmental Science and Resource Management (ESRM), Mawlana Bhashani Science and Technology University (MBSTU) and Designated Reference Institute for Chemical Measurements (DRiCM), Bangladesh Council of Scientific and Industrial

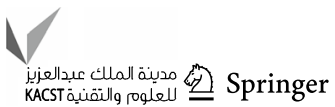


Research (BCSIR) for the laboratory facilities. Thanks are also due to Shimul Roy and Md. Golam Muktadir for their help in different steps of the study. The Ministry of Education (BANBEIS, GARE) of the Peoples' Republic of Bangladesh funded this research, and we are grateful to them.

\section{Compliance with ethical standards}

Conflict of interest There is no conflict of interest regarding this manuscript.

Proper permission from authority Prior permission was taken from Divisional forest officer, Sundarban West Division, Khulna, Bangladesh.

Open Access This article is licensed under a Creative Commons Attribution 4.0 International License, which permits use, sharing, adaptation, distribution and reproduction in any medium or format, as long as you give appropriate credit to the original author(s) and the source, provide a link to the Creative Commons licence, and indicate if changes were made. The images or other third party material in this article are included in the article's Creative Commons licence, unless indicated otherwise in a credit line to the material. If material is not included in the article's Creative Commons licence and your intended use is not permitted by statutory regulation or exceeds the permitted use, you will need to obtain permission directly from the copyright holder. To view a copy of this licence, visit http://creativecommons.org/licenses/by/4.0/.

\section{References}

Akcali I, Kucuksezgin F (2011) A biomonitoring study: heavy metals in macroalgae from eastern Aegean coastal areas. Mar Pollut Bull 62:637-645

Ali AY, Idris AM, Ebrahim AM, Eltayeb MA (2017) Brown al gae (Phaeophyta) for monitoring heavy metals at the Sudanese Red Sea coast. App Water Sci 7(7):3817-3824

Amado Filho GM, Pfeiffer WC (1998) Utilização de macrófitasmarinhas no monitoramento da contaminaçãopormetaispesados: o caso da Baía de Sepetiba RJ. Acta Bot Bras 12(3):411-419

Billah MM, Kamal AHM, Idris MH, Ismail JB, Bhuiyan MKA (2014) $\mathrm{Cu}, \mathrm{Zn}, \mathrm{Fe}$, and $\mathrm{Mn}$ in mangrove ecosystems (sediment, water, oyster, and macroalgae) of Sarawak Malaysia. Zool Ecol 24(4):380-388

Billah MM, Kamal AHM, Idris MH, Ismail JB (2016) Seasonal variation in the occurrence and abundance of mangrove macroalgae in a Malaysian estuary. Algologie 37(2):109-120

Billah MM, Kamal AHM, Idris MH, Ismail JB (2017) Mangrove macroalgae as biomonitors of heavy metalcontamination in a tropical estuary Malaysia. Water Air Soil Pollut 228:347

Brich GF, Olmos MA (2008) Sediment-bound trace elements as indicators of human influence and biological risk in coastal water bodies. ICES J Mar Sci 65:1407-1413

Brito GB, De Souza TL, Bressy FC, Moura CWN, Korn MGA (2012) Levels and spatial distribution of trace elements in macroalgae species from the Todosos Santos Bay, Bahia, Brazil. Mar Pollut Bull 64:2238-2244

Chakraborty S, Bhattacharya T, Singh G, Maity JP (2014) Benthic macroalgae as biological indicators of heavy metal pollution in the marine environments: a biomonitoring approach for pollution assessment. Ecotoxicol Environ Saf 100:61-68

Chakraborty SK, Dutta SM, Ghosh PB, Ray R, Paul AK(2015) Impact of global warming on sundarbans mangrove ecosystem,
India: role of different assessment tools from ecosystem monitoring to molecular markers. Green India: strategic knowledge for combating climate change-prospects and challenges, pp $181-200$

Chatterjee M, Massolo S, Sarkar SK, Bhattacharya AK, Bhattacharya BD, Satpathy KK, Saha S (2009) An assessment of trace element contamination in intertidal sediment cores of wetland, India for evaluating sediment quality guidelines. Environ Monit Assess 150:307-322

Chernova EN (2012) Determination of the background ranges of trace metals in the brown alga Sargassum pallidumfrom the Northwestern Sea of Japan. Russian J Mar Biol 38(3):269-278

Conti ME, Cecchetti G (2003) A biomonitoring study: trace metals in algae and molluscs from Tyrrhenian coastal areas. Environ Res 93:99-112

El-Din NS, Mohamedein LI, El-Moselhy KM (2014) Seaweeds as bioindicators of heavy metals of a hot spot area on the Egyptian Mediterranean Coast during 2008-2010. Environ Monit Assess 186:5865-5881

Filho EV, Silva MP, Jonathan M, Chatterjee SK, Sarkar SM, Sella A, Bhattacharya A, Satpathy KK (2011) Ecological consideration of trace element contamination in sediment cores from Sundarban wetland, India. Environ Earth Sci 63:1213-1225

Gopinath A, Muraleedharan NS, Chandramohanakumar N, Jayalakshmi KV (2011) Statistical significance of biomonitoring of marine algae for trace metal levels in a coral environment. Environ Forens 12(1):98-105

Hatje V, Macedo SC, De Jesus RM, Cotrim G, Garcia KS, De Queiroz AF, Ferreira SLC (2009) Inorganic asspeciation and bioavailability in estuarine sediments of Todosos Santos Bay, BA, Brazil. Mar Pollut Bull 60:2225-2232

Hoq ME (2007) An analysis of fisheries exploitation and management practices in Sundarbans mangrove ecosystem, Bangladesh. Ocean Coast Manage 50:411-427

Hoque MM, Kamal AHM, Idris MHB, Osmanu HA, Saifullah ASM, Billah MM (2015) Status of some fishery resources in a tropical mangrove estuary of Sarawak Malaysia. Mar Biol Res 11(8):834-846

Huang P, Li T, Li A, Yu X, Hu N (2014) Distribution, enrichment and sources of heavy metals in surface sediments of the North Yellow Sea. Cont Shelf Res 73:1-13

Islam MS, Wahab MA (2005) A review on the present status and management of mangrove wetland habitat resources in Bangladesh with emphasis on mangrove fisheries and aquaculture. Hydrobio 542:165-190

Kitamura H, Ishitani H, Kuge Y, Nakamoto M (1982) determination of nitrate in freshwater and seawater by a hydrazine reduction method Suishitu. Odakukenkyu 5:35-42

Kumar JIN, George B, Kumar RN, Sajish PR, Viyol S (2009) Assessment of spatial and temporal fluctuations in water quality of a tropical permanent estuarine esystem-Tapi, west coast India. Appl Ecol Environ Res 7(3):267-276

Kumar RCS, Joseph MM, Kumar GTR, Renjith KR, Manju MN, Kumar CN (2010) Spatial variability and contamination of heavy metals in the intertidal systems of a tropical environment. Int J Environ Res 4(4):691-700

Kumar A, Ramanathan AL, Prabha S, Ranjan RK, Ranjan S, Singh G (2012) Metal speciation studies in the aquifersediments of SemriaOjhapatti, Bhojpur District, Bihar. Environ Monit Assess 184:3027-3042

Kumar A, Ramanathan A, Prasad MBK, Datta D, Kumar M, Sappal SM (2016) Distribution, enrichment, and potential toxicity of trace metals in the surface sediments of Sundarban mangrove ecosystem, Bangladesh: a baseline study before Sundarban oil spill of December 2014. Environ Sci Poll Res 23(9):8985-8999 
Mashitah SM, Shazili NAM, Rashid MKA (2012) Elemental concentrations in brown seaweed, Padina sp. along the east coast of Peninsular Malaysia. Aqua Eco Health Manage 15:267-278

Melville F, Pulkownik A (2006) Investigation of mangrove macroalgae as bioindicators of estuarine contamination. Mar Pollut Bull 52(10):1260-1269

Melville F, Pulkownik A (2007) Investigation of mangrove macroalgae as biomonitors of estuarine metal contamination. Sci Total Environ 387(1-3):301-309

Ozyigit II, Uyanik OL, Sahin NR, Yalcin IE, Demir G (2017) Monitoring the pollution level in Istanbul Coast of the Sea of Marmara using algal species Ulva lactuca L. Polish J Environ Stud 26(2):773-778

Parsons T (1984) A manual of chemical and biological methods for seawater analysis. Pergamon Press, Oxford

Phillips DJH (1990) Use of macroalgae and invertebrates as monitors of metal levels in estuarine and coastal waters. In: Furness RW, Rainbow PS (eds) Heavy metals in the marine environment. CRC, Boca Raton, pp 81-100

Rahman MS, Shah MS, Asaduzzaman, M, Ahsan MN (2003) Water quality characterization of the Sundarbans Reserve Forest (SRF), Khulna for biodiversity consideration, Bangladesh. In: The silver jubilee conference, Ban Chem Soc, pp 67-68

Rahman MM, Rahman MT, Rahaman MS, Rahman F, Ahmad JU, Shakira B, Halim MA (2013) Water quality of the world's largest mangrove forest. Can Chem Trans 1(2):141-156

Rahman MZ, Zaman MFU, Khondoker S, Jaman MH, Hossain ML, Bappa SB (2015) Water quality assessment of a shrimp farm: A study in a salinity prone area of Bangladesh. Int J Fish Aquat Stud 2(5):09-19

Rajfur M, Kłos A (2014) Use of algae in active biomonitoring of surface waters. Eco Chem Eng 21:561-576

Rashid SH, Reinhard B, Hossain ABME, Khan SA (2008) Undergrowth species diversity of Sundarban mangrove forest (Bangladesh) in relation to salinity, pp 41-56

Reis PA, Gonçalves J, Abreu H, Pereira R, Benoit M, O’Mahony F, Connellan I, Maguire J, Ozório R (2016) Seaweed Alariaesculenta as a biomonitor species of metal contamination in Aughinish Bay (Ireland). Ecolo Indic 69:19-25

Rudnick RL, Gao S (2004) Composition of the continental crust. In: Hollands HD, Turekian KC (eds) Treatise on geochemistry, 3rd edn. Elsevier, Amsterdam, pp 1-64

Saifullah ASM, Kamal AHM, Idris MHB, Rajaee AH, Johan I (2014) Seasonal variation of water characteristics in Kuala Sibuti River estuary in Miri, Sarawak Malaysia. Mal J Sci 33(1):9-22
Sarkar SK, Bhattacharya BD (2010) Water quality analysis of the coastal regions of Sundarban mangrove wetland, India using multivariate statistical techniques. Environ Manag 24:159-172

Sawidis T, Brown MT, Zachariadis G, Sratis I (20010 Trace metal concentration in marine macroalgae from different biotopes in Aegean Sea. Environ Int 27:43-47.

Sutherland RA (2000) Bed sediment-associated trace metals in an urbanstream OAHU Hawaii. Environ Geol 39:611-627

Tam NFY, Wong YS (1995) Spatial and temporal variations of heavy metal contamination in sediments of a mangrove swamp in Hong Kong. Mar Pollut Bull 31:254-261

Townend I (2002) Marine science for strategic planning and management: the requirement for estuaries. Mar Pol 26:209-219

Villares R, Puente X, Carballeira A (2005) Seasonal variation and background levels of heavymetals in two green seaweeds. Environ Pollut 119(1):79-90

Wahid SM, Babel MS, Bhuiyan AR (2007) Hydrologic monitoring and analysis in the Sundarbans mangrove ecosystem, Bangladesh. J Hydrol 332:381-395

Weatherburn MW (1967) Phenol hypochlorite reaction for the determination of ammonium. Anal Chem 39:971-974

Yap CK, Ismail A, Tan SG (2003) Background concentrations of Cd, $\mathrm{Cu}, \mathrm{Pb}$, and $\mathrm{Zn}$ in the greenlipped mussel Pernaviridis (Linnaeus) from Peninsular Malaysia. Mar Pollut Bull 46:1043-1048

Zhang J, Liu CL (2002) Riverine composition and estuarine geochemistry of particulate elements in China-weathering features, anthropogenic impact and chemical fluxes. Estuar Coast Shelf Sci 54:1051-1070

Zhang H, Shan B (2008) Historical records of trace element accumulation in sediments and the relationship with agricultural intensification in the Yangtze-Huaihe region, China. Sci Total Environ 399:113-120

Zsefer P, Glasby GP, Sefer K, Pempkowiak J, Kaliszan R (1996) Traceelement pollution in superficial sediments from the southern Baltic Sea off Poland. J Environ Sci Health A 31:2723-2754

Publisher's Note Springer Nature remains neutral with regard to jurisdictional claims in published maps and institutional affiliations. 